\title{
Pelatihan Dan Pengembangan Sumber Daya Manusia
}

\author{
Muhammad Darari Bariqi
}

Program Studi Manajemen Fakultas Ekonomi dan Bisnis

Universitas Trunojoyo Madura

\begin{tabular}{|c|c|}
\hline INFO ARTIKEL & Abstract \\
\hline $\begin{array}{l}\text { Sejarah Artikel: } \\
\text { Diterima : } \\
\text { Diperbaiki : } \\
\text { Disetujui } \quad \\
\text { Keywords: } \\
\text { Kata kunci harus dipilih } \\
\text { dengan cermat dan mampu } \\
\text { mencerminkan } \\
\text { konsep/variabel yang } \\
\text { dikandung dalam artikel, } \\
\text { dengan jumlah antara tiga } \\
\text { sampai enam kata kunci. } \\
\text { Ditulis sesuai urutan abjad } \\
\text { dan antara kata kunci } \\
\text { dipisahkan oleh titik koma (;). }\end{array}$ & \\
\hline & Abstraks \\
\hline $\begin{array}{l}\text { Kata Kunci: } \\
\text { Pengembangan, Sumber Daya } \\
\text { Manusia, Pelatihan } \\
\text { DOI: }\end{array}$ & $\begin{array}{l}\text { Pengembangan SDM sangat diperlukan karena memiliki aspek yang } \\
\text { penting bagi peningkatan produktivitas SDM dan juga memiliki } \\
\text { tujuan-tujuan tertentu yang pastinya harus dicapai demi kemajuan } \\
\text { suatu perusahaan atau organisasi pelayanan sosial. Pengembangan } \\
\text { SDM dapat dilakukan dengan pelatihan. Pelatihan yang dilakukan } \\
\text { oleh lembaga organisasi pelayanan sosial ditujukan untuk } \\
\text { meningkatkan kinerja para SDM. Pelatihan ini biasa dilakukan sesuai } \\
\text { dengan kebutuhan para karyawan. Pelatihan ini terkait dengan } \\
\text { pengelolaan SDM. Menurut Kettner ada } 5 \text { fungsi manajemen, yakni } \\
\text { planning, organizing, HRD, fundraising dan system information. Dan } \\
\text { pelatihan ini berada dalam manajemen HRD. Dalam hal ini, pekerja } \\
\text { sosial penting guna mengetahui manajemen HRD. Dalam hal ini, } \\
\text { metode penelitian yang digunakan adalah metode deskriptif dengan } \\
\text { pendekatan penelitian kualitatif yang dimana hasil penelitian akan } \\
\text { menjabarkan secara deskriptif mengenai proses dari mulainya } \\
\text { ditentukan sasaran pelatihan, kegunaan hingga output dari pelatihan. } \\
\text { Hasil dari penelitian ini diharapkan dapat menjadi evaluasi. }\end{array}$ \\
\hline \multicolumn{2}{|c|}{$\begin{array}{l}\text { Koresponsi: } \\
\text { Nama: Muhammad Darari Bariqi } \\
\text { Email: Bariqi@gmail.com p-ISSN: 2598-7763 } \\
\text { email Bariqi@gmail.com }\end{array}$} \\
\hline
\end{tabular}




\section{Jurnal Studi Manajemen dan Bisnis}

Vol. 5 (2) 2018

\section{PENDAHULUAN}

Keberhasilan suatu perusahaan ditentukan oleh sumber daya yang ada di dalamnya,

terutama sumber daya manusia yang digunakan untuk kelangsungan hidup perusahaan. Sumber daya manusia merupakan subyek yang berperan menentukan keberhasilan perusahaan mencapai tujuannya. Sumber daya manusia merupakan aset perusahaan yang harus dipelihara dan dikembangkan sehingga dapat memberikan kontribusi optimal bagi kelanjutan perusahaan itu sendiri. Sumber daya manusia dalam perusahaan harus dapat meningkatkan kemampuan dan profesionalisme bagi kepentingan perusahaan. Dua aspek potensi manusia yaitu, kuantitas dan kualitas. (M.M. Papayungan, 1995: 110) yang nantinya ditunjukkan dalam aspek yang salah satunya adalah kualitas, hanya dapat dicapai dengan adanya pengembangan sumber daya manusia. Hal tersebut diperlukan karena sumber daya manusia merupakan faktor yang paling mempengaruhi kehidupan

Pelatihan pada hakikatnya adalah proses pembelajaran. Oleh karena itu untuk melatih karyawan, dibutuhkan pengetahuan tentang bagaimana orang belajar. Pada suatu organisasi yang memperhatikan poduktivitas, pendidikan dan pelatihan merupakan fakta yang paling penting. Setiap orang didorong dan dilatih. Dalam hal ini belajar dan berlatih adalah proses tanpa akhir atau sepanjang hayat. Dengan pendidikan dan pelatihan, diharapkan setiap orang dapat meningkatkan keterampilan dan keahliannya. Tidak dapat dipungkiri bahwa orang yang terampil ditambah dengan motivasi kerja yang tinggi sangat berpengaruh terhadap produktivitas kerjanya. Pendidikan berbeda dengan pelatihan. Pelatihan bersifat spesifik dan manfaatnya langsung dapat di praktikan ditempat kerja sedangkan pendidikan bersifat umum dan manfaatnya tidak langsung sebagai saran menambah wawasan, ide dan pengetahuan teoritis. Tujuan pelatihan dan pengembangan karyawan yang telah dikemukakan diatas pada dasarnya dapat disimpulkan bahwa

\section{METODE}

Pendidikan dan pelatihan merupakan upaya untuk mengembangkan sumber daya

aparatur, terutama untuk peningkatan profesionalime yang berkaitan dengan, keterampilan administrasi dan keterampilan manajemen (kepemimpinan). Sebagaimana yang pada intinya tujuan pelatihan dan pengembangan yaitu untuk meningkatkan kemampuan karyawan baik secara afektif (sikap), kognitif (pengetahuan) dan psikomotoriknya (perilaku) serta mempersiapkan karyawan dalam menghadapi perubahan-perubahan yang terjadi sehingga dapat mengatasi hambatan- hambatan yang sekiranya muncul dalam pekerjaan.

Proses pengembangan dan pengelolaan sumber daya manusia merupakan salah satu kunci kesuksesan dari perusahaan agar dapat meningkatkan persaingan dari perusahaan itu sendiri dan meningkatkan brand dari perusaan tersebut. Pengelolaan sumber daya manusia dengan berdaya guna akan mampu mencapai tujuan organisasi. Secara operasional, tujuan organisasi mencakup pada tujuan masyarakat (societal objective), tujuan organisasi (organization objective), tujuan fungsi (functional objective), dan tujuan personal (personal objective). Suatu departemen sumber daya manusia harus memiliki kemampuan untuk mengembangkan, mempergunakan, dan memelihara sumber daya manusia supaya fungsi organisasi dapat berjalan dengan seimbang (Sedarmayanti, 2009).

Hal tentang sumber daya manusia, yang harus diperhatikan oleh manajemen sumber daya manusia adalah dengan memperhatikan tingkat keterampilan karyawan, kemampuan karyawan, dan kapabilitas manajemen dengan keterkaitannya dalam pembuatan strategi sumber daya manusia. Menurut Cahayani (2005), dengan mengetahui tingkat keterampilan dan kemampuan karyawan maka perusahaan dapat menentukan arah strategi sumber daya manusia. Tiga konsep utama dalam strategi sumber daya manusia juga dikemukakan oleh Cahayani (2005), mencakup pada keunggulan kompetitif, kapabilitas khusus, dan kesesuaian strategi. Konsep tersebut harus benar-benar diperhatikan supaya strategi yang dipilih atau ditetapkan oleh suatu perusahaan dapat berjalan dengan efektif..

dikemukakan oleh Soekijo (1999:4) bahwa untuk meningkatkan kualitas kemampuan yang menyangkut kemampuan kerja, berpikir dan keterampilan maka pendidikan dan pelatihan yang paling penting diperlukan.

Menurut Pandodjo dan Husman (1998:4) pendidikan merupakan usaha kegiatan untuk 


\section{KPP Pratama Surabaya Rungkut \\ Muhammad Darari Bariqi}

meningkatkan pengetahuan umum seseorang termasuk di dalamnya teori untuk memutuskan persoalan-persoalan yang menyangkut kegiatan pencapaian tujuan. Sedangkan latihan merupakan kegiatan untuk memperbaiki kemampuan kerja melalui pengetahuan praktis dan penerapannya dalam usaha pencapaian tujuan.

Pelatihan (training) dimaksudkan untuk menguasai berbagai keterampilan dan teknik pelaksanaan kerja tertentu terinci dan rutin (Handoko, 1995:104). Pelatihan merupakan proses pendidikan jangka pendek bagi karyawan operasional untuk memperoleh ketrampilan operasional sistematis. Sedangkan menurut Wijaya (1995:5) pendidikan dan pelatihan akan memberikan bantuan pada masa yang akan datang dengan jalan pengembangan pola pikir dan bertindak, terampil berpengetahuan dan mempunyai sikap serta pengertian yang tepat untuk pelaksanaan pekerjaan.

Salah satu upaya yang dapat dilakukan untuk meningkatkan potensi SDM adalah dengan cara pendidikan dan pelatihan. Kedua istilah tersebut ada terdapat berbagai pendapat, seperti yang dijelaskan oleh Notoatmojo (1998:21) pendidikan pada umumnya berkaitan dengan mempersiapkan calon tenaga kerja yang diperukan oleh sebuah organisasi atau instansi, sedangkan pelatihan berkaitan dengan peningkatan kemampuan atau keterampilan karyawan yang sudah menduduki suatu jabatan. Flippo (1979:53) menyatakan pendidikan

dihubungkan dengan peningkatan pengetahuan umum dan pemahaman akan seluruh lingkungan disekitar kita, sedangkan pelatihan adalah suatu kegiatan untuk meningkatkan ilmu pengetahuan dan keterampilan pegawai dalam pekerjaan yang biasa dilakukan sehari- hari.

Tujuan dan Manfaat Pelatihan

1. Produktivitas (productivity)

Dengan pelatihan akan dapat meningkatkan kemampuan, pengetahuan, keterampilan dan perubahan tingkah laku. Hal ini diharapkan dapat meningkatkan produktivitas organisasi.

2. Kualitas (quality)

Penyelenggaraan pelatihan tidak hanya memperbaiki kualitas pegawai namun diharapkan dapat memperkecil kemungkinan terjadinya kesalahan dalam bekerja. Dengan demikian kualitas dari output yng dihasilkan akan tetap terjaga bahkan meningkat.

3. Perencanaan Tenaga Kerja (human resource planning)

Pelatihan akan memudahkan pegawai untuk mengisi kekosongan jabatan dalam suatu organisasi, sehingga perencanaan pegawai dapat dilakukan sebaik-baiknya. Dalam perencanaan sumber daya manusia salah satu diantaranya mengenai kualitas dan kuantitas dari pegawai dengan kualitas yang sesuai dengan yang diarahakan.

4. Moral (morale)

Diharapkan dengan adanya pelatihan akan dapat meningkatkan prestasi kerja dari pegawai sehingga akan dapat menimbulkan peningkatan upah pegawai. Hal tersebut akan dapat meningkatkan moril kerja pegawai untuk lebih bertanggung jawab terhadap tugasnya.

5. Kompensasi Tidak Langsung (Indirect Compensation)

Pemberian kesempatan kepada pegawai untuk mengikuti pelatihan dapat diartikan sebagai pemberian balas jasa atas prestasi yang telah dicapai pada waktu yang lalu, dimana dengan mengikuti program tersebut pegawai yang bersangkutan mempunyai kesempatan untuk lebih dapat megembangkan diri.

6. Keselamatan dan Kesehatan (health and safety)

Merupakan langkah terbaik dalam mencegah atau mengurangi terjadinya kecelakaan kerja dalam suatu organisasi sehingga akan menciptakan suasana kerja yang tenang, aman dan adanya stabilitas pada sikap mental mereka.

7. Pencegahan Kadaluarsa (obsolescence prevention)

Pelatihan akan mendorong inisiatif dan kreatifitas pegawai, langkah ini diharapkan akan mencegah pegawai dari sifat kadaluarsa. Artinya kemampuan yang dimiliki oleh pegawai dapat menyesuaikan diri dengan perkembangan teknologi.

8. Perkembangan Pribadi (personal growth)

Memberikan kesempatan bagi pegawai untuk meningkatkan pengetahuan dan kemempuan yang dimiliki pegawai termasuk meningkatkan perkembangan pribadinya.

Bentuk-Bentuk Pengembangan Sumber Daya Manusia

Dalam program pengembangan harus dituangkan sasaran, kebijaksanaan prosedur, anggaran, peserta, kurikulum, dan waktu pelaksanaannya. Program pengembangan harus berprinsipkan pada peningkatan efektivitas dan efisiensi kerja masing-masing karyawan pada jabatannya. Program pengembangan suatu organisasi hendaknya diinformasikan secara 


\section{Jurnal Studi Manajemen dan Bisnis \\ Vol. 5 (2) 2018}

terbuka kepada semua karyawan atau anggota supaya mereka mempersiapkan dirinya masingmasing.

Bentuk pengembangan dikelompokkan atas : Pengembangan secara informal,dan pengembangan secara formal (Hasibuan, 2008:72). Untuk lebih jelasnya kedua jenis pengembangan di atas dapat diuraikan sebagai berikut:

a. Pengembangan secara informal

Pengembangan secara informal yaitu karyawan atas keinginan dan usaha sendiri melatih dan mengembangkan dirinya dengan mempelajari buku-buku literatur yang ada hubungannya dengan pekerjaan atau jabatannya. Pengembangan secara informal menunjukkan bahwa karyawan tersebut berkeinginan keras untuk maju dengan cara meningkatkan kemampuan kerjanya. Hal ini bermanfaat bagi perusahaan karena produktivitas kerja karyawan semakin besar, di samping efisiensi dan produktivitasnya juga semakin baik.

b. Pengembangan secara formal

Pengembangan secara formal yaitu karyawan ditugaskan perusahaan untuk mengikuti pendidikan atau latihan, baik yang dilakukan perusahaan maupun yang dilaksanakan oleh lembaga-lembaga pendidikan atau pelatihan. Pengembangan secara formal dilakukan di perusahaan karena tuntutan pekerjaan saat ini ataupun masa datang, sifatnya non karier atau peningkatan karier seorang karyawan.

Pelatihan dan pengembangan (training dan development) memang memerlukan biaya yang cukup besar, namun investasi di bidang manusia tersebut (human investment) akhirnya akan menyumbangkan produktivitas yang sangat tinggi bagi organisasi atau perusahaan. Untuk itu organisasi atau perusahaan tentunya akan memetik laba yang berlipat ganda di waktu yang akan datang.

Program pengembangan karyawan hendaknya disusun secara cermat dan didasarkan kepada metode-metode ilmiah serta berpedoman kepada keterampilan yang dibutuhkan perusahaan saat ini maupun untuk masa depan. Pengembangan harus bertujuan untuk meningkatkan kemampuan teknis, teoritis, konseptual, dan moral karyawan supaya produktivitas kerjanya baik dan mencapai hasil yang optimal.

Tujuan Pengembangan Sumber Daya Manusia Setiap organisasi apapun bentuknya senantiasa akan berupaya dapat tercapainya tujuan organisasi yang bersangkutan dengan efektif dan efisien. Efisiensi maupun efektivitas organisasi sangat tergantung pada baik buruknya pengembangan sumber daya manusia atau anggota organisasi itu sendiri. Ini berarti bahwa sumber daya manusia yang ada dalam organisasi tersebut secara proporsional harus diberikan latihan dan pendidikan yang sebaik- baiknya, bahkan harus sesempurna mungkin.

Pengembangan pada umumnya lebih bersifat filosofis dan teoritis, dibandingkan dengan kegiatan pelatihan. Lagi pula pengembangan lebih diarahkan untuk golongan manajer, sedangkan program pelatihan ditujukan untuk golongan non manajer. Meskipun keduanya ada perbedaan, namun perlu disadari bahwa baik latihan (training) maupun pengembangan (development) keduanya menekan peningkatan keterampilan ataupun kemampuan dalam human relations.

Dari uraian di atas jelas, bahwa tujuan organisasi atau perusahaan akan dapat tercapai dengan baik apabila karyawan dapat menjalankan tugasnya dengan efektif dan efisien. Sehingga untuk itu usaha pengembangan sumber daya manusia dalam organisasi/perusahaan yang bersangkutan sangatlah diperlukan. Dengan demikian dapat ditarik kesimpulan, bahwa tujuan pengembangan sumber daya manusia termaksud adalah untuk memperbaiki efektivitas dan efisiensi kerja mereka dalam melaksanakan dan mencapai sasaran program-program kerja yang telah ditetapkan. Perbaikan efektivitas dan efisiensi karyawan dapat dicapai dengan meningkatkan: pengetahuan, keterampilan dan sikap karyawan terhadap tugas-tugasnya.

Tujuan pengembangan karyawan adalah untuk memperbaiki efektivitas kerja karyawan dalam mencapai hasil-hasil kerja yang telah ditetapkan. Perbaikan efektivitas kerja dapat dilakukan dengan cara memperbaiki pengetahuan karyawan, keterampilan karyawan maupun sikap karyawan itu sendiri terhadap tugas-tugasnya (Heidjrachman dan Husnan, 2004:74).

Pengembangan karyawan bertujuan dan bermanfaat bagi perusahaan, karyawan, konsumen, atau masyarakat yang mengkonsumsi barang/jasa yang dihasilkan perusahaan. Menurut Tohardi (2008 : 70) tujuan pengembangan adalah:

1. Produktivitas.

Dengan pengembangan, produktivitas kerja karyawan akan meningkat, kualitas dan kuantitas produksi akan semakin baik, karena technical skill, human skill dan managerial skill karyawan akan 


\section{KPP Pratama Surabaya Rungkut Muhammad Darari Bariqi}

semakin baik.

2. Efisiensi.

Pengembangan karyawan untuk meningkatkan efisiensi sumber daya manusia, waktu, bahan baku dan mengurangi arusnya mesin-mesin. Pemborosan berkurang, biaya produksi relatif kecil sehingga daya saing perusahaan semakin kecil.

3. Kerusakan.

Pengembangan karyawan bertujuan untuk mengurangi kerusakan barang, produksi dan mesin-mesin karena karyawan semakin ahli dan terampil dalam melaksanakan pekerjaannya.

4. Kecelakaan.

Pengembangan bertujuan untuk mengurangi tingkat kecelakaan karyawan, sehingga jumlah biaya pengobatan yang keluarkan perusahaan berkurang.

5. Pelayanan.

Pengembangan bertujuan untuk meningkatkan pelayanan yang lebih baik dari karyawan kepada nasabah perusahaan, karena pemberian pelayanan yang lebih baik merupakan daya penarik yang sangat penting bagi rekanan-rekanan perusahaan bersangkutan.

6. Moral.

Dengan pengembangan, moral karyawan akan lebih baik karena keahlian dan keterampilannya sesuai dengan pekerjaannya sehingga merek antusias menyelesaikan pekerjaannya dengan baik.

\section{Karier.}

Dengan pengembangan, kesempatan untuk meningkatkan karier karyawan semakin besar, karena keahlian, keterampilan dan prestasi kerjanya lebih baik, promosi ilmiah biasanya didasarkan kepada keahlian dan prestasi kerja seseorang.

8. Konseptual.

Dengan pengembangan, manajer akan semakin cakap dan cepat dalam mengambil keputusan yang lebih baik, karena technical skill, human skill dan managerial skill nya lebih baik.

9. Kepemimpinan.

Dengan pengembangan, kepemimpinan seorang manajer akan lebih baik, human relationsnya lebih luas, motivasi lebih terarah sehingga pembinaan kerja sama vertikal dan horizontal semakin harmonis.

10. Balas Jasa.

Dengan pengembangan, balas jasa (gaji, upah, intensif dan benefit) karyawan akan meningkat karena prestasi kerja mereka semakin besar.

11. Konsumen.

Pengembangan karyawan akan memberikan manfaat yang lebih baik bagi masyarakat konsumen karena mereka akan memperoleh barang atau pelayanan yang lebih bermutu.

\section{SIMPULAN DAN SARAN}

Sebenarnya banyak definisi mengenai pelatihan. Namun pelatihan merupakan upaya yang sistematis dan terencana untuk mengubah atau mengembangkan pengetahuan/keterampilan/sikap melalui pengalaman belajar dalam rangka meningkatkan efektivitas kinerja kegiatan atau berbagai kegiatan. Pelatihan harus dilaksankan dengan sebaikbaiknya agar tujuan dapat dicapai secara efektif dan efisien. Adapun jenis-jenis pelatihan yakni, pelatihan teknis, pelatihan rutin, pelatihan antar pribadi, dan pelatihan pengembangan inovatif. Dalam konteks dunia kerja secara tegas membedakan antara pendidikan dan pelatihan yaitu bahwa pendidikan lebih diarahkan untuk memecahkan knowledge problems, sedangkan pelatihan lebih pada skill peoblems, dan keduanya digunakan bersama untuk memecahkan motivation problems.

Pengembangan SDM (HR development) dapat dipahami sebagai pentiapan individu pegawai untuk memikul tanggung jawab yang berbeda atau lebih tinggi di dalam organisasi. Pengembangan biasanya berhubungan dengan peningkatan kemampuan intelektual atau emosional yang diperlukan untuk menunaikan pekerjaan yang lebih baik. Pengembangan SDM yang membawa misi difokuskan pada peningkatan ketahanan dan kompetensi setiap individu yang terlibat dalam proses pembangunan. Adapun jenis-jenis pengembangan yakni: pengembangan secara informal merupakan pengembangan yang bisa dilakukan atas inisiatif pribadinya. Pengembangan secara formal merupakan pengembangan yang dilakukan oleh organisasi dengan biaya yang cukup besar.

\section{DAFTAR PUSTAKA}

M.M Papayungan.1995. Pengembangan dan Peningkatan Mutu Sumber Daya Manusia

Menuju Masyarakat Industrial Pancasila.Bandung:Mizan

Sedarmayanti. 2009. Sumber Daya Manusia dan Produktivitas Kerja. Bandung: Mandar Maju

Cahayani, Ati. 2005. Strategi dan Kebijakan Manajemen Sumber Daya Manusia. Penerbit Indeks, Jakarta.

Hasibuan, Malayu S. P. 2008. Manajemen Sumber Daya Manusia. Jakarta: PT. Bumi Aksara 


\section{Jurnal Studi Manajemen dan Bisnis}

Vol. 5 (2) 2018

Notoatmodjo, S. 1998. Riset Sumber Daya

Manusia. Jakarta: Gramedia Pustaka Umum

Handoko.T.H. 1995. Manajemen Sumber Daya
Manusia. Jogya: BPEF. 